\title{
Expression and purification of the Lipl41, a surface-exposed lipoprotein antigen of pathogenic Leptospira spp.
}

\author{
Narges Golab ${ }^{1}$, Pejvak Khaki ${ }^{2 *}$, Naser Harzandi', Majid Esmaelizad ${ }^{3}$, \\ and Majid Tebianian ${ }^{4}$

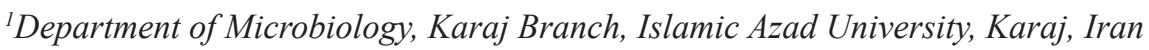 \\ ${ }^{2}$ Department of Microbiology, Razi Vaccine and Serum Research Institute, Agricultural Research, Education and \\ Extension Organization (AREEO), Karaj, Iran \\ ${ }^{3}$ Department of Biotechnology, Razi Vaccine and Serum Research Institute, Agricultural Research, Education and \\ Extension Organization (AREEO), Karaj, Iran \\ ${ }^{4}$ Department of Immunology, Razi Vaccine and Serum Research Institute, Agricultural Research, \\ Education and Extension Organization (AREEO), Karaj, Iran
}

GOLAB, N., P. KHAKI, N. HARZANDI, M. ESMAELIZAD, M. TEBIANIAN: Expression and purification of the Lipl41, a surface-exposed lipoprotein antigen of pathogenic Leptospira spp.. Vet. arhiv 90, 297-305, 2020.

\section{ABSTRACT}

Pathogenic species of Leptospira lead to a zoonotic disease called leptospirosis, which is spread worldwide. A major topic of investigation is to detect the antigens that induce an immune response and to utilize them in diagnostic kits or vaccine development. The outer membrane proteins (OMPs) of Leptospira are potential candidates for this purpose. Lip141 is an OMP that is conserved among pathogenic Leptospira. The aim of this study was to express and purify the Lipl41 recombinant protein in Iranian isolates. All collected Lipl41 protein sequences were compared and analyzed using bioinformatics tools from NCBI databases. Complete codon sequences of the Iranian pattern of Lip141 recombinant protein were codon optimized and sub-cloned into a pET32a + expression vector, and transformed into Escherichia coli BL21 (DE3). Optimal expression of recombinant Lip141 (47kDa) was achieved post-induction with IPTG within the inclusion body. It was then purified by denaturation using serial concentrations of urea, and the recombinant protein was confirmed by western blot. In this study, sufficient amounts of Lipl41 were expressed and purified to be used for the development of a diagnostic kit and subunit vaccine.

Key words: recombinant protein Lip141; expression; purification; pathogenic Leptospira

\section{Introduction}

Leptospirosis is a global zoonotic disease caused by pathogenic Leptospira. It is regularly prevalent in tropical, subtropical and humid parts with high levels of rainfall (ADLER and MOCTEZUMA, 2010), mostly in poor urban areas in developing countries (LOMAR et al., 2000). The clinical syndromes in humans are difficult to differentiate. The manifestations can range from a moderate fever similar to flu, to more serious illnesses presenting with hemorrhage, jaundice, myalgia,

\footnotetext{
*Corresponding author:

Assoc. Prof. Pejvak Khaki, PhD, Head of Department of Microbiology, Razi Vaccine and Serum Research Institute, Agricultural Research, Education and Extension Organization (AREEO), Karaj, Iran, Phone: +98 263457 0038-46; Fax: +98 2634552 194; E-mail: P.khaki@rvsri.ac.ir; Khakipejvak53@gmail.com
} 
renal dysfunction, and aseptic meningitis, which can lead to death in some patients (SEIJO et al., 2002; KHAKI, 2016a). After infection, Leptospira can colonize the renal tubules of a number of wild and domestic animals for prolonged periods, and are discharged through urine into the environment (BURRIEL et al., 2003; MONAHAN et al., 2008). Humans are usually contaminated directly or indirectly by infected animal urine. (MCBRIDE et al., 2005; INANLOU et al., 2015). Due to the widespread animal reservoirs, eradication of leptospirosis is problematic (ZAKERI et al., 2010). Despite vaccination, the disease still survives (KOIZUMI and WATANABE, 2005). Although vaccine development is the main strategy to remove the illness, current drawbacks of wholecell vaccines include short duration of immunity, serovar specificity and side effects (VEDHAGIRI et al., 2009; LIN et al., 2016). Thus, the production of an efficient vaccine with lower levels of toxicity is essential to control and eliminate this disease (DELLAGOSTIN et al., 2011). Many studies on the development of recombinant vaccines against leptospirosis have used conserved outer membrane proteins (OMPs) such as Lip121, Lipl32, Lip141, Ompl1, etc (VEDHAGIRI et al., 2009; MEGUDESWARAN et al., 2014; LIN et al., 2016; CHANDY et al., 2017). OMPs revealed on the surface are among the most impressive antigens that can affect immune responses throughout the course of the disease. (FLANNERY etal., 2001; OLIVEIRA et al., 2015). There are three classes of leptospiral OM proteins $(O M P S)$ which consist of lipoproteins, trans membrane proteins and peripheral membrane proteins (SHANG et al., 1996; ADLER et al., 2011). Regarding abundance, Lipl41 (41kDa) is the third among OM lipoproteins (CULLEN et al., 2005). This protein is an immunogenic antigen and expressed only in the pathogenic Leptospira, but notably absent in nonpathogenic species (KHAKI et al., 2016b), and has been considered as an indicator in serodiagnosis of the disease (HAAKE et al., 1999; MARIYA et al., 2006). Results of earlier studies have also shown that Lip141 is surface exposed and expressed during infection in mammalian hosts (SENTHILKUMAR et al., 2007; KING et el., 2013). Therefore, it may be considered a potential subunit vaccine candidate against leptospirosis and, moreover, could be useful in a diagnostic kit. (SRIVASTAVA, 2006; SRIKRAM et al., 2011). Hence, in this present study, our aim was to express and purify Iranian isolates of the Lip141 r protein of pathogenic Leptospira to develop a recombinant antigen.

\section{Materials and methods}

Bioinformatics studies and generation of Lipl41 construct. Twenty-seven complete coding sequences of Lip141 protein 1065bp (355aa) from six prevalent pathogenic Leptospira serovars, consisting of eleven from Iran, such as: serovar Canicola, serovar Autumnalis, serovar Hardjo, serovar Icterohaemorrhagiae, serovar Pomona, serovar Grippotyphosa, and sixteen lipl41 sequences from other countries available in NCBI database were collected from GenBank (https://www.ncbi. nlm.nih.gov/GenBank) by using the BLAST online software (https://blast.ncbi.nlm..nih.gov/Blast.cgi) (Table 1). All collected protein sequences were compared and analyzed using bioinformatics tools such as MegAlign software.

A partial sequence of Lipl41, including coding sequences of amino acids number 21 to 355 (1005 bp) minus signal peptide (first 20aa), was synthesized by General Biosystems, Inc, USA. In addition, pET-32a + was used to produce a $47 \mathrm{kDa}$ TRX-Lip141 fusion protein. EcoR I- Sal I restriction sites were used for sub cloning into the pET-32a+ vector and the His-Tag sequence was considered for affinity purification. Codon optimization of Lip141 was carried out for better expression in Escherichia coli with $\mathrm{pET} 32 \mathrm{a}+$ expression vector.

Expression. The recombinant plasmid of pET32aLip141 was transformed into $E$. coli BL21 (DE3) as the host strain, on LB Agar containing $50 \mu \mathrm{g} / \mathrm{mL}$ ampicillin by the heat shock method (SAMBROOK and RUSSEL, 2001). Then a matrix plate was subcultured, and one single colony of it was cultured in $5 \mathrm{~mL} \mathrm{LB}$ broth medium, supplemented with 5 $\mu \mathrm{g} / \mathrm{mL}$ Ampicillin at $37^{\circ} \mathrm{C}$ overnight. One $\mathrm{mL}$ of this suspension was inoculated onto $50 \mathrm{~mL} 2 \mathrm{YT} /$ AMP broth medium for induction. When the optical density reached $0.6 \mathrm{~A}_{600}$, the recombinant plasmid was induced with Isopropyl- $\beta$-D-Thio Galacto 
N. Golab et al.: Expression and purification of the Lip141, a surface-exposed lipoprotein antigen of pathogenic Leptospira spp.

Table 1. List of LipL41 sequences of Leptospira interrogans used in this study

\begin{tabular}{|c|c|c|c|}
\hline Protein Id & Serovar & Strain & Country \\
\hline AAT48499.1 & Australis & $65-9$ & China \\
\hline BAE48274.1 & Australis & Akiyami C & Japan \\
\hline AAV88037.1 & Australis & $65-9$ & China \\
\hline AHW80383.1 & Autumnalis & RTCC2802 & Iran \\
\hline AAT48498.1 & Autumnalis & $\operatorname{Lin} 4$ & China \\
\hline BAE48272.1 & Autumnalis & Akiyami A & Japan \\
\hline AHW80387.1 & Canicola & RTCC2824 & Iran \\
\hline AAT48495.1 & Canicola & Lin & China \\
\hline AHX26958.1 & Canicola & RTCC2805 & Iran \\
\hline AAT65971.1 & Canicola & -------- & India \\
\hline AHW80384.1 & Hardjo & RTCC2810 & Iran \\
\hline AAT65970.1 & Hardjo & ------- & India \\
\hline AHX26962.1 & Hardjo & RTCC 2821 & Iran \\
\hline AHW80386.1 & Icterohaemorrhagiae & RTCC2823 & Iran \\
\hline AHX26960.1 & Icterohaemorrhagiae & RTCC2812 & Iran \\
\hline ACV53831.1 & Icterohaemorrhagiae & - ------ & India \\
\hline AAS21814.1 & Kremastos & Kremastos & USA \\
\hline AHW80385.1 & Pomona & RTCC2822 & Iran \\
\hline AHX26961.1 & Pomona & RTCC 2815 & Iran \\
\hline AAU04601.1 & Pomona & Luo & China \\
\hline AAV88038.1 & Pomona & Luo & China \\
\hline AAS21818.1 & Pomona & PomonaRZ11 & USA \\
\hline AHA11954.1 & Pomona & Pomona $\mathrm{P}$ & Argentina \\
\hline AHW80388.1 & Grippotyphosa & RTCC2825 & Iran \\
\hline AFH54361.1 & Grippotyphosa & Moskva V & India \\
\hline AAT48501.1 & Grippotyphosa & Lin 6 & China \\
\hline AHX26959.1 & Grippotyphosa & RTCC 2808 & Iran \\
\hline
\end{tabular}

Pyranoside (IPTG). Sampling was performed before and after induction at different times $(0-4$ $\mathrm{h}$ and also16 h). Different incubation temperatures $\left(22\right.$ and $\left.37^{\circ} \mathrm{C}\right)$ and various concentrations $(0.1$ to $0.5 \mathrm{mM})$ of IPTG were analyzed. The induced cells were harvested by centrifuge at $5000 \mathrm{~g}$ at $4{ }^{\circ} \mathrm{C}$ for $5 \mathrm{~min}$. The pellets were suspended in 1XPBS (137 $\mathrm{mMNaCl}, 2 \mathrm{mMKH}_{2} \mathrm{PO}_{4}, 10 \mathrm{mM} \mathrm{Na} \mathrm{HPO}_{4}, 2.7$ $\mathrm{mMKCl}, \mathrm{pH} 7.4)$ with sample buffer added (5× solution of $250 \mathrm{mMTris.HCl}, \mathrm{pH} 6.8,10 \% \mathrm{SDS}$, $30 \%$ (v/v) Glycerol, $10 \mathrm{mM}$ DTT, 0.05\% (w/v) bromophenol blue, 2-Mercaptoethanol), boiled for $5 \mathrm{~min}$, then analyzed by SDS-PAGE using a 10\% polyacrylamide gel along with Unstained protein markers (Thermo Scientific, USA). The gel was stained for $2 \mathrm{hr}$ by standard Coomassie brilliant blue R-250 and distained with 45\% methanol, $10 \%$ acetic acid glacial solution. Induced cells were resuspended in PBS with $10 \mathrm{mM}$ imidazole, and sonicated five times for 1 minute on ice with one minute intervals. After that, Phenyl Methyl Sulfonyl Fluoride (PMSF) was added to inhibit protease activity. The cell lysate was centrifuged at $15,000 \mathrm{~g}$ at $4{ }^{\circ} \mathrm{C}$ for $15 \mathrm{~min}$. The supernatant and pellet analyzed by SDS-PAGE. 
Protein purification and immunoblotting. The rLip41 protein was purified from the post sonication pellets under denaturation conditions using serial concentrations of 1 to $8 \mathrm{M}$ urea in PBS buffer at 37 ${ }^{\circ} \mathrm{C}$. The post sonication pellets were suspended in 5 $\mathrm{mL} 1 \mathrm{M}$ urea and shacked for $1 \mathrm{~h}$ in $37^{\circ} \mathrm{C}$. Washing with 2 to $5 \mathrm{M}$ urea was done for 1 hour, and the 6 to $8 \mathrm{M}$ concentrations of urea were incubated overnight. Purified proteins were dialyzed in $1 \mathrm{X}$ PBS and assessed by $10 \%$ SDS-PAGE, then stored at $-70{ }^{\circ} \mathrm{C}$ for further analysis.

Western-blotting was performed. The blocking step was performed by $1 \%$ BSA in PBS containing $0.1 \%$ Tween 20 , then probed with a HRP conjugated anti-6x His-Tag antibodies (Abcam, USA) (diluted 1:5,000). 4-choloro-1-naphthol was used for developing the protein band.

Protein assay. Quantitation of recombinant protein was performed by Bradford protein assay. To achieve a standard curve, various concentrations of $0.25 \mathrm{mg} / \mathrm{mL}$ BSA (Bovine Serum Albumin) were utilized. Ten dilutions of BSA were prepared in range of 0 to $10 \mu \mathrm{g} / \mu \mathrm{L}$ protein as a standard lane in deionized water. $200 \mu \mathrm{L}$ Bradford reagent was added to all dilutions containing BSA and recombinant protein up to $1 \mathrm{~mL}$ final volume.

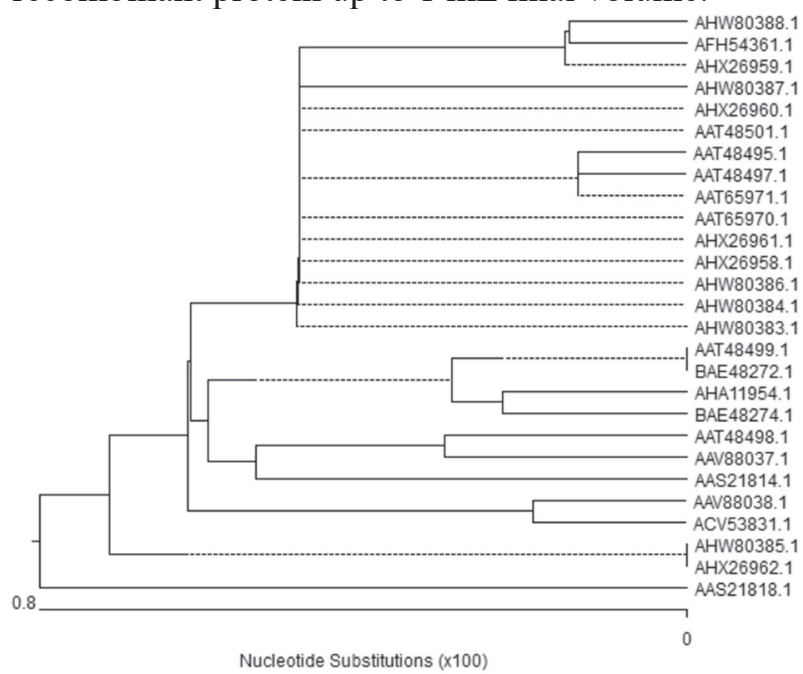

Fig. 1. Phylogenetic analysis of six leptospira interrogans serovars, including eleven from Iran and sixteen from other countries submitted to GenBank (protein Id). The phylogenetic tree based on LipL41 protein sequences used Megalign software.

\section{Results}

Phylogenetic analysis of full length LipL41 proteins (355aa) showed 0.8 percent divergence between six serovars of leptospira interrogans in Iran and the other countries (as shown in Fig. 1). Multiple Alignment of LipL41 protein sequences using MegAlign software identified significant amino acid substitutions had taken place among the serovars. Notably, 20 different amino acid substitutions were detected, 8 of which were observed among some Iranian isolates, as stipulated below: in Iranian Leptospira serovar Grippothyphosa (AHW80388.1) and (AHX26959.1) isolates, 3 amino acid substitutions were found in residues 146,212 and $312(\mathrm{I} 146 \rightarrow \mathrm{V} 146, \mathrm{~F} 212 \rightarrow \mathrm{Y} 212$ and $\mathrm{T} 312 \rightarrow \mathrm{A} 312)$. Furthermore, in serovar Pomona (AHW80385.1) and serovar Hardjo (AHX26962.1) one amino acid substitution was observed in residue 204 (V204 $\rightarrow$ I204). On the basis of these polymorphisms, the local Lip141 protein pattern was used to design the construct.

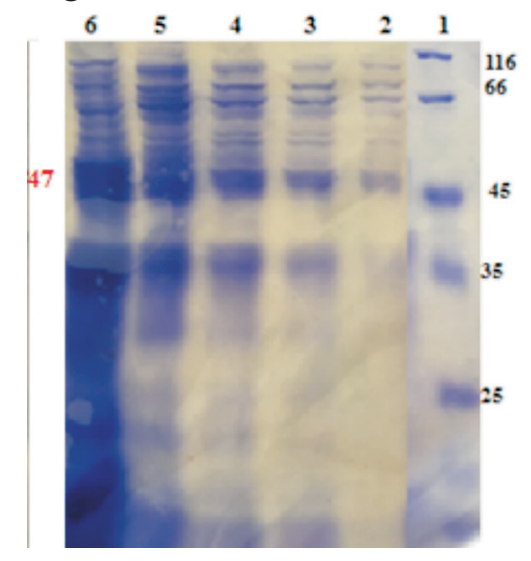

Fig. 2 . SDS-PAGE (12\%) analysis of the expressed rLip141 protein in BL21 (DE3) which was induced by $0.1 \mathrm{mM}$ IPTG at different times. Lane 1: Unstained protein molecular weight marker $(\mathrm{kDa})$, (Thermo, scientific). Lane2: non-induced cell lysate. Lane 3: induced (1h) cell lysate. Lane 4: induced ( $3 \mathrm{~h})$ cell lysate. Lane 5: induced (4 h) cell lysate. Lane 6: induced (over-night) cell lysate.

Recombinant protein was induced at different times, temperatures and various concentrations of IPTG. The protein electrophoresis by SDS-PAGE analysis revealed a distinct band that corresponded to successful induction of full-length $47 \mathrm{kDa}$ Lip141 protein. However, maximum expression of the Lip141 recombinant protein was observed at $4 \mathrm{~h}$ 
post induction incubation at $37^{\circ} \mathrm{C}$ in the presence of $0.1 \mathrm{mM}$ IPTG (Fig. 2).

Analysis of the cell lysate post-sonication demonstrated that the recombinant protein was mostly found in the pellet, not in the supernatant.

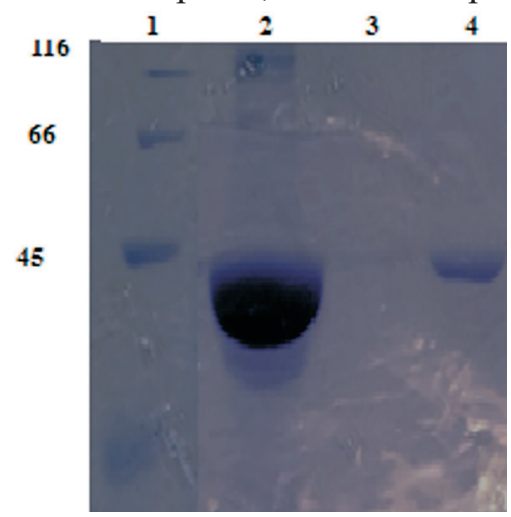

Fig. 3. Analysis of the purified Lip141 recombinant protein $(47 \mathrm{kDa})$ with SDS PAGE followed by Coomassie blue staining. Lane 1: unstained protein molecular weight marker (kDa), (Thermo, scientific).

Lane 2: purified Lipl41 protein with $6 \mathrm{M}$ urea concentration. Lane 3: purified Lip141 protein with 8M urea concentration. Lane 4: purified Lipl41 protein with $7 \mathrm{M}$ urea concentration.

1

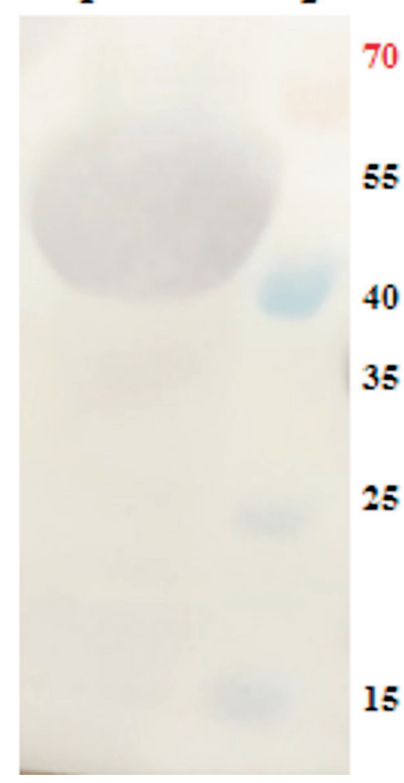

Fig. 4. Western blot analysis of the purified Lip141 recombinant protein using HRP-conjugated Anti His-

Tag antibody. Lane 1: Lipl41Purified recombinant protein $(47 \mathrm{kDa})$ in SDS PAGE. Lane 2: Prestained Protein Molecular Weight ladder (Thermo, scientific).
The protein was purified after washing in serial concentrations of urea in PBS (1 to $5 \mathrm{M})$ and then solubilized in $(6$ to $8 \mathrm{M})$ at $37{ }^{\circ} \mathrm{C}$. The results of protein purification in all three concentrations of urea (6 to $8 \mathrm{M}$ ) showed a sharp single band (at $47 \mathrm{KDa})$. Moreover, the protein obtained from purification with an urea concentration of $6 \mathrm{M}$ had the maximum protein concentration (Fig. 3). The yield of purified recombinant protein was estimated to be $28.3 \mathrm{mg} / \mathrm{mL}$.

Western blot confirmed the distinct $47 \mathrm{kDa}$ band (Fig. 4).

\section{Discussion}

In recent years many studies have been conducted on the identification, expression, and characterization of the leptospiral OMPs, such as OmpL1, Omp52, LipL21, LipL36, LipL41, etc (HAAKE and MATSUNAGA, 2002; SENTHILKUMAR et al., 2007; DEZHBORD et al., 2014; HOSEINPUR et al., 2015; SOLTANI et al., 2015). Some other studies revealed that, unlike leptospiral LPS, OMPS are generally well conserved, not serovar specific and able to induce cross-protective immunity (KOIZUMI and WATANABE, 2005; OLIVEIRA et al., 2015). In addition, leptospiral OMPs are commonly exposed on the surface and are among the first antigens that interact with host immune cells (CULLEN et al., 2002; NALLY et al., 2007).

One of the most important OMPS expressed during human infection is Lip141, a $41 \mathrm{kDa}$ lipoprotein that is highly conserved in pathogenic Leptospira species. (MEGUDESWARAN et al., 2014) Furthermore, Lip141 has been determined as a hemin-binding protein (LIN et al., 2013), and is one of the key virulence factors involved in hostpathogen contact. Thus, it appears that Lip141 may play an important role in inducing immunological responses in the host (GUERREIRO et al., 2001).

According to previous reports, the use of Lip141 of pathogenic Leptospira in a multi-serovar ELISA enhanced the sensitivity of the test (THEODORIDIS etal., 2005; NATARAJASEENIVASANetal.,2008). Another investigation conducted by MARIYA et al in 2006 demonstrated that Lip141 antigen in ELISA 
is a possible candidate for serodiagnosis of bovine leptospiral infection. Moreover, earlier studies indicated that this protein is expressed throughout acute infection (KING et al., 2013), and may be susceptible to the host immune defenses, either by itself or in combination with OmpL1 (HAAKE et al., 1999; LIN et al., 2011).

Consequently, Lip141 could be considered a genus-specific antigen for improvement of new broad spectrum vaccines and serodiagnostic techniques against leptospirosis.

Therefore, our study focused on the expression and purification of Lipl41 protein of Iranian pathogenic Leptospira in E. coli. We used BLAST software to gather all the protein sequences of Lip141 of pathogenic Leptospira from different serovars from Iran and other countries available in the NCBI database. A significant finding in our study was the detection of 8 amino acid subsituations in some Iranian isolates, which, to our knowledge, have not been reported in the literature. Gene construct was then designed according the pattern of local Lip141 protein prevalent pathogenic Leptospira isolates.

Induction of the recombinant protein using various concentrations of IPTG was performed at different times and temperatures, which demonstrated the maximum expression of Lip141 recombinant protein in BL21 (DE3) at $37{ }^{\circ} \mathrm{C}$ and $0.1 \mathrm{mM}$ IPTG at 4 hours post induction. A high level of expression of Lipl41 was observed (28.38 $\mathrm{mg} / \mathrm{mL}$ ). Hence, under these conditions, optimal recombinant protein purification was achieved as one distinct band, with an approximate molecular weight of $47 \mathrm{kDa}$. On the basis of our results, the blotted protein (using HRP-conjugated Anti anti-6x His-Tag Ab) verified the presence of the recombinant Lip141protein as illustrated in Fig. 4.

Some researchers have obtained high expression rates of this protein using either pET series (MEGUDESWARAN et al., 2014; LIN et al., 2016) or other similar expression vectors (MARIYA et al., 2006; KING et al., 2013; LIN et al., 2013). Solubility is an important factor for producing recombinant proteins in heterologous expression systems. Due to differences in folding structure, soluble recombinant proteins are usually considerably easier to purify compared with insoluble ones (COSTA et al., 2014). Despite the use of the TRX tag sequence during gene construction to enhance solubility, a significant amount of the recombinant protein was found in the inclusion body, while lesser quantities were detected in the supernatant, and expressed in the insoluble form. These results agreed with other studies where the over expressed Lip141 was observed mostly in the inclusion body, and purified under denaturing conditions (MARIYA et al., 2006; KING et al., 2013; LIN et al., 2013). Although in one report this protein was solubilized with $6 \mathrm{M}$ guanidine, (HAAKE et al., 1999), in this study we used 1-8 M urea according to the manual protocol (to be under published). This provided an efficient and cost-effective method which is applicable for purification of Lip141 insoluble proteins.

\section{Conclusion}

In conclusion, this study demonstrated 0.8 percent divergence between Lip141 protein sequences of Iranian and foreign Leptospira interrogans serovars. 8 amino acid subsituations were identified among local serovars which were used to design the gene construct. It was successfully expressed in E. coli BL 21(DE3) and purified by denaturation, using serial concentrations of urea.

The presence of purified protein was confirmed with SDS-PAGE analysis and western blotting.

Therefore, the possible immunogenicity of this recombinant protein was demonstrated, and it may have the potential to induce effective protective immunity against leptospirosis in the future. However, the serodiagnostic ability of this recombinant protein as a capture antigen in the ELISA method in animal and human subjects requires further investigation.

\section{Acknowledgements}

This study was supported by a grant (Number: 12-18-18106-96045-961023) from Razi Vaccine and Serum Research Institute, Agricultural Research, Education and Extension Organization (AREEO), Karaj, Iran.

\section{References}

ADLER, B., A. DE LA PEÑA MOCTEZUMA (2010): Leptospira and leptospirosis. Vet. Microbiol. 140, 287-296. DOI: 10.1016/j.vetmic.2009.03.012 
N. Golab et al.: Expression and purification of the Lip141, a surface-exposed lipoprotein antigen of pathogenic Leptospira spp.

ADLER, B., M. LO, T. SEEMANN, G. L. MURRAY (2011): Pathogenesis of leptospirosis: the influence of genomics. Vet. Microbiol. 153, 73-81.

DOI: 10.1016/j.vetmic.2011.02.055

BURRIEL, A. R., C. DALLEY, M. J. WOODWARD (2003): Prevalence of Leptospira species among farmed and domestic animals in Greece. Vet. Rec. 153, 146-148.

DOI: $10.1136 / v r .153 .5 .146$

CHANDY, S., L. KIRUBANANDHAN, P. HEMAVATHY, A. M. KHADEEJA, S. J. KURIAN, K. VENKATARAMAN, K. MØRCH, D. MATHAI, A. MANOHARAN (2017): Serovar prevalence of Leptospira in semirural India and the development of an IgM-based indirect ELISA. J. Infect. Dev. Ctries. 11, 234-241.

DOI: $10.3855 /$ jidc. 8067

COSTA, S., A. AlmeIDA, A. CASTRO, L. DOMINGUES (2014): Fusion tags for protein solubility, purification, and immunogenicity in Escherichia coli: the novel Fh8 system. Front. Microbiol. 5, 63.

DOI: $10.3389 /$ fmicb.2014.00063

CULLEN, P. A,. S. J. CORDWELL, D. M. BULACH, D. A. HAAKE, B. ADLER, (2002): Global analysis of outer membrane proteins from Leptospira interrogans serovar Lai. Infect. Immun. 70, 2311-2318.

DOI: $10.1128 /$ iai.70.5.2311-2318.2002

CUllen, P. A., X. XU, J. MATSUNAGA, Y. SANCHEZ, A.I. KO, D. A. Haake, B. Adler (2005): Surfaceome of Leptospira spp. Infect. Immun 73, 4853-4863.

DOI: $10.1128 /$ IAI.73.8.4853-4863

DELlAGOSTIN, O. A., A. A. GRASSMANN, D.D. HARTWIG, S. R. FELIX, E. F. DA SILVA, A. J. McBRIDE (2011); Recombinant vaccines against leptospirosis. Hum. Vaccin. 7, 1215-24.

DOI: $10.4161 / \mathrm{hv} \cdot 7.11 .17944$

DEZHBORD, M., M. ESMAELIZAD, P. KHAKI, F. FOTOHI, A. ZAREHPARVAR MOGHADDAM (2014): Molecular identification of the ompL1 gene within Leptospira interrogans standard serovars. J. Infect. Dev. Ctries. 8, 688-693.

DOI: $10.3855 /$ jidc. 3174

FLANNERY, B., D. COSTA, F. P. CARVALHO, H. GUERREIRO. J. MATSUNAGA, E. D. DA SILVA, A. G. FERREIRA, L. W. RILEY, M. G. REIS, D. A. HAAKE, A. L. KO (2001): Evaluation of recombinant Leptospira antigen-based Enzyme-Linked Immunosorbent assays for the serodiagnosis of Leptospirosis. J. Clin. Microbiol. 39, 3303-3310.

DOI: $10.1128 /$ JCM.39.9.3303-3310.2001.

GUERREIRO, H., J. CRODA, B. FLANNERY, M. MAZEL, J. MATSUNAGA, M. GALVÃO REIS, P. N. LEVETT, A. I. KO, D. A. HAAKE (2001): Leptospiral proteins recognized during the humoral immune response to leptospirosis in humans. Infect. Immun. 69, 4958-4968.

DOI: 10.1128/IAI.69.8.4958-4968.2001
HAAKE, D. A., M. K. MAZEL, A. M. MCCOY, F. MILWARD, G. CHAO, J. MATSUNAGA, E. A. WAGAR (1999): Leptospiral outer membrane proteins Ompl1 and Lipl41exhibit synergistic immunoprotection. Infect. Immun. 67, 6572-6582.

DOI: 0019-9567/99/\$04.00+0

HAAKE, D. A., J. MATSUNAGA (2002): Characterization of the leptospiral outer membrane and description of three novel leptospiral membrane proteins. Inf. Immun. 70, 4936-4945.

DOI: $10.1128 /$ iai.70.9.4936-4945.2002

HOSEINPUR, H., P. KHAKI, M. NOOFELI, S. MORADIBIDHENDI (2015): Molecular detection of pathogenic leptospiral serovars by PCR, based on lipL21 gene. Arch. Razi Inst. 70, 223-227.

DOI: 10.7508/ari.2015.04.001

INANLOU, F., P. KHAKI, N. MOHAMMADPOUR, S. MORADI BIDHENDI, H. ZOLFAGHARIAN, Y. F. CHANG, M. R. BAZRAFSHAN, F. SARAEI (2015): Preparation of microspheres containing leptospiral antigen using biodegradable alginate epolymers. Vet. arhiv 85, 395-406

KHAKI, P. (2016a): Clinical laboratory diagnosis of human leptospirosis, Int. J. Enteric. Pathog. 4: e31859.

DOI: $10.17795 /$ ijep31859.

KHAKI, P., S. MORADIBIDHENDI, Y. F. CHANG, M. S. SOLTANI, K. TADAION (2016b): Amplification and cloning of a gene encoding a $41 \mathrm{kDa}$ outer membrane protein (LipL41) of Leptospira interrogans serovar Canicola. Infect. Epidemiol. Med. 2, 5-7.

DOI: $10.7508 /$ iem.2016.03.002

KING, A. M., T. BARTPHO, R. W. SERMSWAN, D. M. BULACH, A. ESHGHI, M.PICARDEAU, B. ADLER, G. L. MURRAY (2013): Leptospiral outer membrane protein Lip141 is not essential for acute leptospirosis but requires a small chaperone protein, Lep, for stable expression. infect. Immun. 81, 2768-2776.

DOI: $10.1128 /$ iai.00531-13

KOIZUMI, N., H.WATANABE (2005): Leptospirosis vaccines: past, present, and future. J. Postgrad. Med. 51, 210-4.

LIN, X., A. SUN, P. RUAN, Z. ZHANG, J. YAN (2011): Characterization of conserved combined $\mathrm{T}$ and $\mathrm{B}$ cell epitopes in leptospira interrogans major outer membrane proteins OmpL1 and LipL41. BMC Microbiol. 11, 21.

DOI: $10.1186 / 1471-2180-11-21$

LIN, M. H., Y. C. CHANG, C. D. HSIAO, S. H. HUANG, M. S. WANG, Y. C. KO, C. W. YANG, Y. J. SUN (2013): LipL41, a hemin binding protein from Leptospira santarosai serovar Shermani. PLOS ONE. 8(12)

DOI: 10.1371/journal.pone.0083246.

LIN, X., G. XIAO, D. LUO, L. KONG, X. CHEN, D. SUN, J. YAN (2016): Chimeric epitope vaccine against Leptospira interrogans infection and induced specific immunity in guinea pigs. BMC Microbiol. 16, 241.

DOI: 10.1186/s12866-016-0852-y 
N. Golab et al.: Expression and purification of the Lip141, a surface-exposed lipoprotein antigen of pathogenic Leptospira spp.

LOMAR, A. V., D. DIAMENT, J. R. TORRES (2000): Leptospirosis in Latin America. Infect. Dis. Clin. North Am. 14, 23-39.

DOI: $10.1016 / \mathrm{S} 0891-5520(05) 70216-6$

McBRIDE A. J., D. A. ATHANAZIO, M. G. REIS, A. I. KO (2005): Leptospirosis. Curr. Opin. Infect. Dis. 18, 376-86. DOI: 10.1097/01.qco.0000178824.05715.2c

MARIYA, R., P. CHAUDHARY, A. A. KUMAR, E. THANGAPANDIAN, R. AMUTHA, S. K. SRIVASTAVA (2006): Evaluation of a recombinant LipL41 antigen of Leptospira interrogans serovar Canicola in ELISA for serodiagnosis of bovine Leptospirosis. Com. Immunol. Microbiol. Infect. Dis. 29, 269-277.

DOI: 10.1016/j.cimid.2006.06.007

MEGUDESWARAN, S. K., M. PARTHIBAN, S. RAJENDRAN, S. SENTHILKUMAR, G. RAVIKUMAR (2014): Evidence of cross reaction potential recombinant Leptospira LipL41 Protein. Indian. J. Biotechnol. 13, 5761.

MONAHAN, A. M., J. J. CALLANAN, J. E. NALLY (2008): Proteomic analysis of leptospira interrogans shed in urine of chronically infected hosts. Infect. Immun. 76, 49524958.

DOI: 10.1128/IAI.00511-08

NALLY, J. E., J. P. WHITELEGGE, S. BASSILIAN, D. R. BLANCO, M. A. LOVETT (2007): Characterization of the outer membrane proteome of Leptospira interrogans expressed during acute lethal infection. Infect. Immune. 75, 766-773.

DOI: 10.1128/IAI.00741-06.

NATARAJASEENIVASAN, K., P. VIJAYACHARI, S. SHARMA, A. P. SUGUNAN, J. SELVIN, S. C. SEHGAL (2008) Serodiagnosis of severe leptospirosis: evaluation of ELISA based on the recombinant OmpL1 or LipL41 antigens of Leptospira interrogans serovar autumnalis. Ann. Trop. Med. Parasitol. 102, 699-708.

DOI: $10.1179 / 136485908 X 355229$

OLIVEIRA, T. L., A. A. GRASSMANN, R. A. SCHUCH, A. C. P. SEIXAS NETO, M. MENDONÇA, D. D HARTWIG, A. J. A. MCBRIDE, O. A. DELlAGOSTIN (2015): Evaluation of the Leptospira interrogans Outer Membrane Protein OmpL37 as a vaccine candidate. PLOS one. 10(11), e0142821.

DOI: 10.1371/journal.pone.0142821

SAMBROOK, J., D. W. RUSSEL (2001): Molecular Cloning. Cold Spring Harbor Laboratory Press, Heatshock.

SEIJO, A., H. COTO, J. SAN JUAN, J. VIDELA, B. DEODATO, B. CERNIGOI, O. G. MESSINA, O. COLLIA, D. DE BASSADONI, R. SCHTIRBU, A. OLENCHUK, G. D. DE MAZZONELLI, A. PARMA (2002): Lethal leptospiral pulmonary hemorrhage: an emerging disease in Buenos Aires, Argentina. Emerg. Infect. Dis. 8, 1004-1005. DOI: $10.3201 /$ eid0809.010499
SENTHILKUMAR, T. M. A., M. SUBATHRA, P.RAMADASS (2007): Evaluation of recombinant leptospiral antigen LipL41 in enzyme-linked immunosorbent assay and latex agglutination test for serodiagnosis of canine leptospirosis. Vet. arhiv 77, 475-484.

SHANG, E. S., T. A. SUMMERS, D. A. HAAKE (1996): Molecular cloning and sequence analysis of the gene encoding LipL41, a surface-exposed lipoprotein of pathogenic Leptospira species. Infect. Immun. 64, 23222330 .

SOLTANI, M. S., P. KHAKI, S. MORADI BIDHENDI, M. H. SHAHHOSSEINY (2015): Molecular characterization of the LipL41 gene of Leptospira interrogans vaccinal serovars in Iran. Arch. Razi Inst. 70, 145-150.

DOI: 10.7508/ari.2015.03.001

SRIKRAM, A., K. ZHANG, T. BARTPHO, M. LO, D. E. HOKE, R. W. SERMSWAN, B. ADLER, G. L. MURRAY (2011): Cross-protective immunity against leptospirosis elicited by a live, attenuated lipopolysaccharide mutant. J. Infect. Dis. 203, 870-879.

DOI: $10.1093 /$ infdis/jiq127

SRIVASTAVA, S. K (2006): Prospects of developing leptospiral vaccines for animals. Indian. J. Med. Microbiol. 24, 331-336.

THEODORIDIS, D., J. BÖHMER, M. HOMUTH, K. STRUTZBERG-MINDER(2005): Development of a novel ELISA for serodiagnosis of Leptospirosis and additional detection of pathogenic Leptospira by polymerase chain reaction for veterinary routine diagnostics. Rev. Cubana. Med. Trop. 57, 49-50.

VEDHAGIRI, K., K. NATARAJASEENIVASAN, P. CHELLAPANDI, S. G. PRABHAKARAN, J. SELVIN, S. SHARMA, P. VIJAYACHARI (2009): Evolutionary implication of outer membrane lipoprotein-encoding genes ompl1, lipl32 and lipl41 of pathogenic leptospira species. Genom. Proteom. Bioinf. 7, 96-106.

DOI: 10.1016/S1672-0229(08)60038-8

ZAKERI, S, N. KHORAMI, Z. F. GANJI, N. SEPAHIAN, A. A. MALMASI, M. M. GOUYA, N. D. DJADID (2010): Leptospira wolffi, a potential new pathogenic Leptospira species detected in human, sheep and dog. Inf. Gen. Evol. 10, 273-277.

DOI: $10.1016 /$ j.meegid.2010.01.001 
N. Golab et al.: Expression and purification of the Lip141, a surface-exposed lipoprotein antigen of pathogenic Leptospira spp.

Received: 31 August 2019

Accepted: 21 May 2020

\section{GOLAB, N., P. KHAKI, N. HARZANDI, M. ESMAELIZAD, M. TEBIANIAN: Ekspresija i pročišćavanje površinskog lipoproteinskog antigena Lipl41 iz patogenih bakterija roda Leptospira. Vet. arhiv 90, 297-305, 2020.}

\section{SAŽETAK}

Patogene vrste Leptospira uzrokuju zoonotsku bolest leptospirozu koja je raširena u cijelom svijetu. Cilj istraživanja bio je dokazati antigene koji potiču imunosni odgovor i mogu se primijeniti u dijagnostičkim kompletima ili za razvoj cjepiva. Vanjska proteinska membrana (OMPs) leptospira potencijalni je kandidat za tu svrhu, a gen Lip141 je dobro očuvan među patogenim leptospirama. Ekspresija i pročišćavanje rekombinantnog proteina Lip141 provedeno je u izolatima iz Irana. Uspoređene su sve prikupljene sekvencije proteina Lip141 i analizirane bioinformatičkim alatom iz baze podataka NCBI. Kompletne sekvencije kodona rekombinantnog proteina Lip141 u izolatima su optimizirane, zatim subklonirane u pET32a + vektor i pretvorene u bakteriju Escherichia coli BL21 (DE3). Optimalna ekspresija rekombinantnog Lipl41 (47kDa) postignuta je post-indukcijski pomoću isopropyl $\beta$-d-1-thiogalactopyranoside (IPTG). Zatim je pročišćena denaturacijom što je uključilo primjenu serijskih koncentracija ureje. Rekombinantni protein je potvrđen metodom western blot. Istraživanje potvrđuje mogućnost ostvarenja dostatne količine i ekspresije pročišćenog Lip141 da se može upotrijebiti za razvoj dijagnostičkih kompleta i subjediničnih cjepiva.

Ključne riječi: rekombinirani protein Lip141; ekspresija; pročišćavanje; patogena Leptospira 
